\title{
lodine Mineral Status of Etawah Crossbred Goat at Different Physiological Stages Fed Elephant Grass and Tofu Byproduct
}

\author{
Widiyanto ${ }^{*}$, Sumarsono, Sudjatmogo, BWHE Prasetiyono, A Setiadi and Surahmanto \\ Faculty of Animal Science and Agriculture, Diponegoro University, Tembalang Campus, Semarang 50275, \\ Central Java-Indonesia \\ \#Corresponding author email: wid_ds@yahoo.com
}

\begin{abstract}
The objective of the study was to determine the iodine status and to map the thyroxin hormone concentration in etawah crossbred goat (ECG) at different physiological stages and its interrelation to the nutrition and performance. Fifteen female ECG was allotted in three physiolgical stage groups: female kid, young female goat and lactating goat, fed elephant grass and tofu byproduct. The study was conducted in Tossa Shakti Agro Company (TSA), Central Java, Indonesia. Analysis of variance in completely randomized design was used to determine the effect of physiological stages on soil and feed iodine content, blood serum thyroxin hormone concentration, nutrient and feed dry matter consumption, average daily gain and milk production. Result showed that soil iodine content was adequate to stimulate plant growth $(3.109 \mathrm{mg} / \mathrm{kg})$. Consumed feed iodine content was adequate to all physiological stages, female kid, young female and lactating goat (1.003; 0.940 and $0.820 \mathrm{mg} / \mathrm{kg}$, respectively). Thyroxin hormone concentration in blood serum of female kid and young female goat was in normal range $(8.23$ and $10.05 \mu \mathrm{g} / \mathrm{dl})$ but the concentration of thyroxin hormone in blood serum of lactating goat was marginal $(6.17 \mu \mathrm{g} / \mathrm{dl})$. Iodine supplementation was required for lactating etawa crossbred goat if tofu byproduct was included in its ration.
\end{abstract}

Key words : nutrient, iodine, thyroxin hormone, etawah crossbred goat

Abstrak. Penelitian ini bertujuan mengkaji status iodine dan memetakan konsentrasi hormone tiroksin kambing peranakan etawah (PE) pada berbagai status fisiologis dan interelasinya dengan status nutrisi serta performans ternak. Sebanyak 15 ekor kambing PE betina digunakan dalam penelitian yang terbagi atas tiga kelompok status fisiologis, yakni: cempe betina, kambing dara dan kambing laktasi. Sebagai pakan, digunakan rumput gajah dan ampas tahu. Penelitian ini dilakukan di PT. Tossa Shakti Agro (TSA) Kendal, Jawa Tengah. Variabel yang diukur meliputi kandungan iodin tanah dan pakan, kadar hormon tiroksin serum darah, konsumsi bahan kering pakan dan nutrien, pertambahan bobot badan serta produksi susu. Data yang terkumpul diolah secara statistik dengan analisis variansi dalam rancangan acak lengkap guna mengetahui pengaruh status fisiologis terhadap variable-variabel tersebut. Hasil penelitian menunjukkan bahwa kandungan iodine tanah memadai untuk menstimulasi pertumbuhan tanaman $(3,109 \mathrm{mg} / \mathrm{kg})$. Kandungn iodin pakan terkonsumsi memadai untuk semua status fisiologis, dalam hal ini cempe betina, kambing dara dan kambing laktasi (masing-masing: 1,003; 0,940 dan 0,820 mg/kg). Konsentrasi hormon tiroksin serum darah cempe betina dan kambing dara dalam kisaran normal (8,23 dan 10,05 ug/dl), tetapi konsentrasi hormon tiroksin serum darah kambing laktasi berada pada batas normal (borderline), yakni 6,17 ug/dl. Suplementasi iodin diperlukan bagi kambing peranakan etawa yang sedang laktasi, jika ampas tahu digunakan sebagai bagian dari ransum.

Kata kunci: nutrien, iodin, hormone , kambing peranakan etawah

\section{Introduction}

lodine is one of micro minerals that play a significant role in metabolism that in turn influence animal productivity. lodine content in forage or grass is generally limited. Grass roughly contains $200-400 \mu \mathrm{g} / \mathrm{kg} \quad \mathrm{DM}$.
Approximately, $30-50 \%$ of iodine in the feedstuff perishes during the storage time. lodine critical level in goat ration was 300 $\mu \mathrm{g} /$ day (Kearl, 1982). lodine content is influenced by age and body measurement. lodine content in the animal is related to 
metabolic rate difference (Bourdoux, 1998). lodine content decreases as the animals age. Usually small animal has more iodine content than the bigger animal. lodine in animal tissue is known as in-organic and organic iodine (tironin and its metabolites) (Ranjhan, 1980).

lodine in animal body is particularly the component of thyroid hormone and its importance is reflected in metabolic role of thyroxin hormone or $3^{\prime}, 5^{\prime}, 3,5$ tetraiodotironin (T4) dan 3',3,5 triiodotironin (T3) (Todini, 2007). Thyroxin hormone (T4) is the main secreted product (77\%) of thyroid gland (Todini, 2007). Thus, thyroxin hormone concentration in the blood is one of important indicator of animal iodine status (Iveta et al., 2011). Thyroxin hormone (T4) is thyroid hormone which is important to transport and negative feedback regulation whereas $\mathrm{T} 3$ is active form of thyroid hormone in target cell (Altiner, 2006). Small amounts of T3 were synthesized in the thyroid gland, most of which derived from T4 deiodination in several tissues, particularly liver and kidney (Todini, 2007). Thyroxin hormone has role on thermoregulation, energy and protein metabolism, and animal metabolic response on nutritional and environment changes (Huszenicza, 2002). Thyroxine significance in metabolism is also reflected in its influences on growth, reproduction, mammary gland development and milk production regulation (Novoselec, 2009).

lodine is not included in essential mineral for plant but $0.5-1 \mathrm{mg} / \mathrm{kg}$ iodine in the soil can stimulate forage growth (Weng et al., 2008; Landini et al., 2011). lodine up to $10 \mathrm{mg} / \mathrm{kg}$ in the soil can be toxic for plant (Umaly and Poel, 1970). Amachi et al. (2005) stated that the sea is the main source of iodine. lodine can be transferred from the sea water to atmosphere through iodine molecular volatilization (12) or organic iodine form such as $\mathrm{CH}_{3} \mathrm{l}, \mathrm{CH}_{2} \mathrm{I}_{2}$ and $\mathrm{C}_{2} \mathrm{H}_{5} \mathrm{l}$ produced by sea organisms. lodine is then transferred to soil through wet and dry deposition. The phenomenon causes low iodine content in forage at hilly area, iodine deficiency in animals besides owing to errosion and leaching.

According to Kearl (1982), young ruminant, early pregnant and non lactating ruminant need feed with $0.25 \mathrm{mg} / \mathrm{kg}$ iodine, while lactating ruminant needs $0.5 \mathrm{mg} / \mathrm{kg}$ iodine. lodine toxic level in feed was $50-100 \mathrm{mg} / \mathrm{kg}$ (Iveta et al., 2002). Small ruminants are less sensitive to iodine intoxication than the big ones (Paulikova et al., 2002). Meschy (2000) stated goat needs more iodine content in feed than other ruminants; furthermore $0.3 \mathrm{mg} / \mathrm{kg}$ iodine is insufficient to prevent goiter in kid. According to NRC (2007) iodine content in feed should be $0.5 \mathrm{mg} / \mathrm{kg} \mathrm{DM}$ for growing goat and non lactating goat, and $0.8 \mathrm{mg} / \mathrm{kg} \mathrm{DM}$ for lactating goat. Feedstuff containing goitrogenic compound ie, cyanide and isoflavon could inhibit iodine utilization by thyroid gland implied on low thyroxin hormone and decreased animal's performance/productivity (Todini, 2007).

lodine status in animal is reflected by thyroid hormone concentration in blood serum, related to physiological stage. Normal concentration of the hormone is 6.10-8.30 $\mu \mathrm{g} / \mathrm{dl}$ (Todini, 2007). According to Iveta et al. (2011), thyroid hormone concentration was influenced by metabolic load. Todini (2007) stated that high metabolic load also stimulated deoidination of T4 to a more active T3, thereby decreasing T4 concentration. Metabolic load which influenced the supply rate and utilization of that thyroid hormone varied according to animal physiological stage (Nudda et al., 2009). Metabolic load of female kid is higher than that of young female goat, as of lactating goat is higher than that of goat with two previous physiological stages (Meschy, 2000; Novoselec et al., 2009).

Central Java province has the highest goat population in Indonesia (21.34\%) compared to 
other provinces. Central Java also has local breed goat namely Etawah crossbred goat (ECG) or Kaligesing goat in Purworejo regency. The ECG is the cross mating between kacang goat and etawah goat (EG). The ECG has developed well since 1925 and genetically served as dual purpose goat. Kaligesing ECG race is local breed natural from Indonesia. Obst and Napitupulu (1984) stated that productivity of ECG in Indonesia was low (0.45-2.2 kg/day), compared the its optimal milk production capacity $(2-3 \mathrm{~kg} /$ day $)$. The ECG production centre is usually in upland area.

The research was conducted to study the iodine status and to map the thyroxin hormone based on physiological stages of ECG which fed the elephnat grass and tofu byproduct. The information obtained would be used to determine the supplementation of iodine in the ration, formulation the mineral supplement with iodine enrichment, and proper supplementation time.

\section{Materials and Methods}

Fifteen female ECG were used in the study. Ration consisted of elephant grass and tofu byproduct meal. Elephant grass was harvested from the grass planted in the surrounding company (TSA) area. Tofu by product was bought from outside company. The distance of that area to the coastline was about $10 \mathrm{~km}$ with hilly and wavy topography.

Fifteen female ECG were allotted in 3 groups of female kid, young female goat and secondmid stage lactating goat with average body weight of 13.12, 19.62 and $40.72 \mathrm{~kg}$, respectively. Each group had 5 heads as replication.

Venoject tube was used to collect blood sample from vena jugularis in goat. The research was done in one month. Soil sample was composite of 5 subsamples from 5 points from 3 different places in the grass production area of TSA. The soil sample was collected from $20 \mathrm{~cm}$ deep. The grass samples were obtained from the same locations with the soil samples obtained, and then were composited.

lodine content in the soil, thyroxin hormone (T4) content in blood serum, feed dry matter intake, nutrient and iodine content in feed, average daily gain, growth rate and milk production were observed. Iodine content in the soil was extracted by Watts and Mitchell method (2009), then measured using high performance liquid chromatography (HPLC). lodine status in the grass was determined by colorimetric (Bourdoux, 1998). Thyroxin hormone (T4) in blood serum was determined by commercial ELISA kit and micro-titrimetric plates. Nutrient composition (Table 1) was determined use proximate analysis according to Weende method (Harris, 1970). The feed intake was determined by subtract the feed given and the feed unconsumed. Average daily gain was measured by weighing the initial weight and final weight during the experiment. Milk productions were the average of milk production in early, middle and the end during the study. The obtained data were analyzed by Analysis of Variance and were processed by Costat statistic programme.

Table 1. Nutritional composition of the experimental diets (DM basis)

\begin{tabular}{lcccccc}
\hline \multicolumn{1}{c}{ Ingredients } & $\mathrm{CP}(\mathrm{g} / \mathrm{kg})$ & $\mathrm{CF}(\mathrm{g} / \mathrm{kg})$ & $\mathrm{NFE}(\mathrm{g} / \mathrm{kg})$ & $\mathrm{EE}(\mathrm{g} / \mathrm{kg})$ & Ash & $\mathrm{TDN}$ \\
\hline Elephant grass & 95.2 & 311.3 & 418.2 & 22.7 & 152.6 & 554.3 \\
Tofu by product & 210.8 & 242.5 & 417.4 & 97.1 & 32.2 & 718.5 \\
\hline
\end{tabular}

CP : Crude protein ; CF : crude fiber ; NFE: nitrogen free extract ; EE : ether extract ; TDN : total digestible nutrient 


\section{Results and Discussion}

lodine status of animal is resultant of several factors which interact each other and reflected among other in blood serum thyroxin hormone concentration. The factors are iodine content in the soil, iodine content in the feed, nutrient consumption and physiological stage of animal

As shown in Table 2, soil iodine content was $3.09 \mathrm{mg} / \mathrm{kg}$. lodine was not classified as essential mineral for plant, but $0.5-1 \mathrm{mg} / \mathrm{kg}$ iodine in the soil could stimulate the plant growth (Weng et al., 2008; Landini et al., 2011).

Table 2. Soil iodine concentration and iodine concentration in feed (DM basis)

\begin{tabular}{lc}
\hline Ingredient & Iodine content $(\mathrm{mg} / \mathrm{kg})$ \\
\hline Soil & 3.09 \\
Elephant grass & 1.503 \\
Tofu byproduct & 0.068 \\
\hline
\end{tabular}

Soil iodine content is toxic for plant if the content reaches $10 \mathrm{mg} / \mathrm{kg}$ (Umaly and Poel, 1970). The soil iodine content in the study area was fit, even the topography of research area was hilly which is sensitive to errosion and leaching. The TSA Company was located near the coastal area. Amachi et al., (2005) stated that major iodine sources in the soil come from the sea. Further they stated that iodine could be transferred from sea water to atmosphere through iodine molecular volatilization $\left(\mathrm{I}_{2}\right)$ or organic iodine form as $\mathrm{CH}_{3} \mathrm{I}, \mathrm{CH}_{2} \mathrm{I}_{2}$, or $\mathrm{C}_{2} \mathrm{H}_{5} \mathrm{I}$ which is produced by sea organisms, then the iodine was transferred to the soil through wet and dry deposition.

Elephant grass is the main feed in this investigation, so the grass is the main sources of iodine consumed by the goat. The iodine content in elephant grass was $1.503 \mathrm{mg} / \mathrm{kg}$ dry matter basis (Table 2). Kearl (1982) stated that young ruminant, early pregnant and non lactation need feed with the iodine content was $0.25 \mathrm{mg} / \mathrm{kg}$, while for lactating ruminant need iodine content was $0.5 \mathrm{mg} / \mathrm{kg}$. The iodine is toxic when the content was $50-100 \mathrm{mg} / \mathrm{kg}$. The small ruminant is less sensitive to toxicity than that of big ruminant (Paulikovaet al., 2002). Meschy (2000) stated that iodine content required in goat feed was higher than that of other ruminant species. $0.3 \mathrm{mg} / \mathrm{kg}$ iodine was inadequate to prevent the goiter in goat kids. Feed iodine content recommended by NRC (2007) was $0.5 \mathrm{mg} / \mathrm{kg}$ for goat in growth phase and $0.8 \mathrm{mg} / \mathrm{kg}$ for goat in lactation phase. lodine content in grass was adequate to support the goat requirement at all physiological stages (Kearl, 1982; Meschy, 2000; NRC., 2007).

Elephant grass and tofu byproduct were given to goat in this investigation. lodine content in tofu by product analysis showed the result as $0.068 \mathrm{mg} / \mathrm{kg}$, whereas in elephant grass was $1.503 \mathrm{mg} / \mathrm{kg}$. The iodine content in elephant grass and tofu byproduct was shown in Table 2. Calculation based on iodine content in elephant grass and tofu byproduct (Table 2.) and dry matter consumption of both feeds ingredients (Table 3 ) showed that daily iodine consumption were $0.37 ; 0.41$ and $0.77 \mathrm{mg} /$ day in female kid, youngfemale goat and lactating goat respectively, with proportion were : 1.001; 0.942 and $0.818 \mathrm{mg} / \mathrm{kg}$ of consumed dry matter. Thyroxin hormone concentration in blood serum reflected the iodine status of animal. lodine concentration in blood serum related with the iodine supply, main nutrient, performance and physiological stage of animal (Haenlein and Anke, 2011). lodine concentration in blood serum on female kid, young female goat and lactating goat was shown in Table 4.

Thyroxin hormone concentration on blood serum was highest $(P<0.05)$ in young female goat, the concentration was $10.05 \mu \mathrm{g} / \mathrm{dl}$. The concentrations of the hormone in female kid and lactating goat were 8.23 and $6.17 \mu \mathrm{g} / \mathrm{dl}$, respectively. The thyroxin hormone concentration on blood serum was located in 
Table 3. Feed intake, crude protein, TDN and iodine intake (mean $\pm \mathrm{SE}$ ), dry matter basis

\begin{tabular}{|c|c|c|c|}
\hline \multirow[t]{2}{*}{ Consumption } & \multicolumn{3}{|c|}{ Physiological stage } \\
\hline & Female kid & Young female goat & Lactating goat \\
\hline \multicolumn{4}{|l|}{ Feed intake } \\
\hline Daily average (g/day) & $368^{c} \pm 4.0$ & $437^{b} \pm 12.2$ & $943^{\mathrm{a}} \pm 18.4$ \\
\hline Percentage from body weight (\%) & $2.83^{\mathrm{a}} \pm 0.087$ & $2.24^{b} \pm 0.127$ & $2.23^{b} \pm 0.053$ \\
\hline Elephant grass proportion (\%) & $65.18^{\mathrm{a}} \pm 0.837$ & $61.16^{b} \pm 0.525$ & $52.32^{c} \pm 0.268$ \\
\hline Tofu byproduct proportion (\%) & $34.82^{\mathrm{C}} \pm 0.837$ & $38.84^{b} \pm 0.525$ & $47.68^{\mathrm{a}} \pm 0.601$ \\
\hline Dry matter waste (g/day) & $40^{\mathrm{a}} \pm 2.4$ & $22^{b} \pm 2.6$ & $34^{\mathrm{a}} \pm 2.9$ \\
\hline \multicolumn{4}{|l|}{$\mathrm{CP}$ intake } \\
\hline Daily average (g/day) & $49.86^{c} \pm 0.618$ & $61.17^{b} \pm 1.759$ & $141.74^{\mathrm{a}} \pm 2.641$ \\
\hline Percentage from dry matter (\%) & $13.53^{c} \pm 0.098$ & $14.01^{b} \pm 0.062$ & $15.03^{\mathrm{a}} \pm 0.031$ \\
\hline \multicolumn{4}{|l|}{ TDN intake } \\
\hline Daily average (g/day) & $225^{c} \pm 2.4$ & $270^{b} \pm 7.5$ & $596^{\mathrm{a}} \pm 11.5$ \\
\hline Percentage from dry matter (\%) & $61.14^{c} \pm 0.138$ & $61.80^{b} \pm 0.087$ & $63.26^{\mathrm{a}} \pm 0.045$ \\
\hline \multicolumn{4}{|l|}{ lodine intake } \\
\hline Daily average $(\mathrm{mg} /$ day) & $0.37^{c} \pm 0.006$ & $0.41^{\mathrm{b}} \pm 0.027$ & $0.77^{\mathrm{a}} \pm 0.017$ \\
\hline Proportion from dry matter $(\mathrm{mg} / \mathrm{kg})$ & $1.001^{\mathrm{a}} \pm 0.0124$ & $0.942^{b} \pm 0.0072$ & $0.818^{c} \pm 0.0039$ \\
\hline
\end{tabular}

Table 4. Thyroxin hormone concentration (T4) in blood serum and goat performance(mean $\pm \mathrm{SE}$ )

\begin{tabular}{lccc}
\hline Item & Female kid & Young female goat & Lactating goat \\
\hline Thyroxin hormone concentration $(\mathrm{T} 4)(\mu \mathrm{g} / \mathrm{dL})$ & $8.23^{\mathrm{b}} \pm 0.20$ & $10.05^{\mathrm{a}} \pm 0.07$ & $6.17 \mathrm{c} \pm 0.18$ \\
Average daily gain $(\mathrm{g} /$ day) & $55^{\mathrm{a}} \pm 0.67$ & $61^{\mathrm{a}} \pm 1.03$ & $26^{\mathrm{b}} \pm 2.11$ \\
Growth rate $(\%)$ & $0.37^{\mathrm{a}} \pm 0.026$ & $0.28^{\mathrm{b}} \pm 0.003$ & $0.06^{\mathrm{c}} \pm 0.003$ \\
Milk production $(\mathrm{mL})$ & - & - & $850 \pm 17.39$ \\
\hline
\end{tabular}

Values bearing different superscripts within row are significantly different $(P<0.05)$

normal number, as $6.10-8.30 \mu \mathrm{g} / \mathrm{dl}$. The result was supported by adequate consumed feed iodine level (Table 3) according to NRC (2007). The thyroxin hormone concentration was highest in the young female goat because the use and supply rate in the tissue of young female goat was lower than goat in other physiological stages (female kid and lactating goat), at was the case for supported the maintenance and the lower growth rate $(P<0.05)$ than female kid namely 0.28 vs $0.37 \%$ (Table 4). The supply rate of thyroxin hormone to female kid tissue was higher than that of young female goat, because its metabolic load was greater than young female goat (Iveta et al., 2011). The high metabolic load could stimulate deiodination of $\mathrm{T} 4$ to be T3 which more active so could reduce the T4 concentration (Todini, 2007; Todini et al., 2007; Abdollahi et al., 2013).
The high metabolic load to milk production and the iodine excretion with milk, cause the thyroxin hormone concentration in lactating goat blood serum was lower than other physiological stages goat, thus the hormone concentration in borderline, namely $6.17 \mu \mathrm{g} / \mathrm{dl}$. Goat excrete the iodine in the milk is higher than other ruminant species (Flachowsky et al., 2014). Nudda et al. (2009) stated that iodine excreted through dairy cattle milk was $2 \%$ but in goat could reach $94 \%$ from iodine consumed daily. Thyroid hormone concentration was found in lactation goat might be caused by goitrogenic compound in tofu byproduct which could reduce the iodine utilization to thyroxin hormone synthesis. Feed consumption data (Table 3) showed that proportion of tofu byproduct consumption was highest in lactation goat compared to those in kid and young goat (47.68vs 38.84 and $34.82 \%$ ). 
Ni'mah (2009) stated that Tofu by product contains isoflavon consisted of genistein and daidezein, as 65.93 and $63.68 \mathrm{mg} / 100 \mathrm{~g}$, repectively. Isoflavon is the compound which can reduce the thyroxin hormone synthesis through inhibite the thyroid peroxidase activity one enzyme could catalyzed the thyrosin residual iodination in thyroid gland (Dillingham et al., 2007; Somjen et al., 2012). Kearl (1982) stated that iodine supply needed to be doubled than normal requirement in ration with goitrogenic compound. lodine status on lactation ECG was expected has impact on low milk production. As shown in Table 4, average daily milk production was $850 \mathrm{ml}$, while the potency of milk production between $2-3 \mathrm{~kg} /$ day (Obst and Napitupulu, 1984).

The low milk production might be caused by the low feed consumption even the nutrient composition was adequate for goat, as CP 15.03\% and TDN 63.26\% (Table 3). According to Ranjhan (1982), the requirements of dairy goat with $40 \mathrm{~kg}$ body weight in second mid lactation period with ADG $20 \mathrm{~g} /$ day were $10 \% \mathrm{CP}$ and 55 \%TDN respectively. The low performance of goat was caused by inadequate of feed dry matter consumption, so that the consumed nutrient not adequate. The consumption of feed dry matter was only $2.23 \%$ from body weight but the dry matter consumption according to Ranjhan (1980) should be $4 \%$ from the body weight. The requirement of $\mathrm{CP}$ and TDN for dairy goat with $40 \mathrm{~kg}$ body weight were $145.6 \mathrm{~g}$ and $880 \mathrm{~g}$, but in this study, the consumption of CP was only $141.74 \mathrm{~g}$ and the TDN consumption was only $596 \mathrm{~g} / \mathrm{head} /$ day (Table 3.). The body weight of lactating goat tends to increase, as $26 \mathrm{~g} /$ day (Table 4). That phenomenon might be due to delaying of lipid and carbohydrate catabolism along with the level of thyroxin (T4) hormone at the borderline, so that the increasing of fat deposition in adipose tissue was occured (Biondi, 2010). According to Swanson and Miller
(1973), decreasing of milk production caused by hypothyroidism resulted in increasing of energy supply to body weight gain. Thrift et al. (1999) reported that lactating Brahman cattle with inductive hypothyroidism for 84 days showed the decreasing of milk production and higher increasing of body weight gain than control group, namely 54.6 vs. $15.7 \mathrm{~kg}(\mathrm{P}<0.01)$

Average daily gain (ADG) of female kid and young female goat were 55 and $61 \mathrm{~g}$ respectively (Table 4). The ECG was the large breed type, which according to Ranjhan (1980) its average daily gain could reach 86 for female kid with $14 \mathrm{~kg}$ body weight, and $100 \mathrm{~g} /$ day for young female goat with $20 \mathrm{~kg}$ body weight. The adequate consumed feed iodine and blood serum thyroxin (T4) hormone concentration showed that the low performance (ADG) of that female kid and young female goat was caused by inadequate consumed nutrient as result of inadequate feed dry matter intake. The dry matter intake of female kid and young female goat was 368 and 437, respectively (Table 3). The dry matter intake just $2.83 \%$ and $2.24 \%$ from its body weight, that amount was lower than the requirement as $4.1 \%$ and $4.0 \%$ (Ranjhan, 1980). The inadequate feed intake is also reflected by the average daily dry matter wasted of female kid, young female goat and lactating goat, namely 40; 22 and $34 \mathrm{~g} /$ day respectively (Table 3). Harris (1970) stated that voluntary intake was reached when the averge daily dry matter wasted was 100-200 $\mathrm{g} / \mathrm{head} /$ day. Inadequate dry matter intake caused low nutrient consumption, inadequate to produce optimal average daily gain. The CP and TDN consumption on female kid were 49.86 and $225 \mathrm{~g} / \mathrm{head} /$ day respectively, while the $\mathrm{CP}$ and TDN consumption of young female goat were 61.17 and $270 \mathrm{~g} /$ day respectively (Table 3). On the other hand, CP and TDN requirement for female kid were 109.8 and 384 $\mathrm{g} /$ day, while the CP and TDN requirement for young female goat were 101.6 and $520 \mathrm{~g} /$ day. 


\section{Conclusion}

There was the influence of physiological stages on iodine status of goat. The thyroxin (T4) hormone concentration in blood serum of young goat was greater than those of female kid and lactating goat. The lowest blood serum thyroxin hormone (T4) concentration was found in lactating goat. Feeding tofu byproduct as one of ration component where iodine level in ration were in normal range, resulted in normal blood serum thyroxin hormone concentration in female kid and young female goat, whereas in lactating goat was borderline. lodine supplementation was required for lactating etawa crossbred goat, if tofu byproduct was included in its ration.

\section{Acknowledgement}

The research team thank to dean of Animal and Agricultural Sciences Faculty Diponegoro University and head of Master of Animal Science program study for funding the research and TSA management for research permit.

\section{References}

Abdollahi E, H Kohram and MH Shahir. 2013. Plasma concentration of essential trace microminerals and thyroid hormones during single or twin pregnancies in fat-tailed ewes. Small Rum. Res. 113(2-3): 360-364.

Altiner A. 2006. Study of serum growth hormone, 3,5,3'-triiodothyronine, thyroxine, total protein and free fatty cids levels during parturition and early lactation in ewes. Bulletin of the Veterinary Institute in Pulawy. 50:85-87.

Amachi S, T Fujii, H Shinoyama and Y Muramatsu. 2005. Microbial influences on the mobility and transformation of radioactive iodine in the environment. J. Nuclear and Radiochemical Sci. 6:21-24.

Biondi. 2010. Thyroid and obesity : an intriguing relationship. J. Clinical Endocrinology and Metabolism. 95(8):3614-3617.

Bourdoux P. 1998. Evaluation of iodine intake : problems of the iodine/creatinine ratiocomparison with iodine excretion and daily fluctuations of iodine concentration.
Experimental Clinical Endocrinology Diabetes J. 106(3):17-20.

Dillingham BL, BL McVeigh, JW Lampe and AM Duncan. 2007. Soy protein isolates of varied isoflavone content do not influence serum thyroid hormones in healthy young men. Thyroid. 17(2):131-137.

Flachowsky G, K Franke, U Meyer, M Leitererand and $F$ Schone. 2014. Influencing factors on iodine content of cow milk. European J Nutrition. 53(2):351-365.

Haenlein GFWand M Anke. 2011. Mineral and trace element in goats: A review. Small Rum. Res. 95(1):2-19.

Harris LE. 1970. Nutrition Research Techniques for Domestic and Wild Animals. Vol. 1. Animal 5501$7 \mathrm{pp}$.

Huszenicza GY, M Kulcsar and P Rudas. 2002. Clinical endocrinology of thyroid gland function in ruminants. Veterinary Medicine-Czech. 47(7):199-210.

Iveta P, G Kovac, J Bires, S Paulik, H Seidel and O Nagy. 2002. lodine toxicity in ruminant. Veterinary Medicine-Czech. 47(12):343-350.

Iveta P, H seidel, O Nagy, C Tothova and G Kovac. 2011. Concentrations of thyroid hormones in various age categories of ruminants and swine. Acta veterinaria. 61(5-6):489-503.

Kearl LC. 1982. Nutrient Requirement of Ruminnts in Developing Countries. International Feedstuffs Institute Utah Agricultural Experiment Station Utah State university Logan Utah USA. $381 \mathrm{pp}$.

Landini M, S Gonzali and P Perata. 2011. lodine biofortification in tomato. J Plant Nutrition and Soil Sci. 174:480-486.

Meschy F. 2000. Recent progress in the assessment of mineral requirements of goats. Livestock Prod. Sci. 64:9-14.

Ni'mah RJ 2009. Kadar Genistein dan Daidzein pada Kedelai, Ampas Tahu dan Oncom Merah. Tesis. Institut Pertanian Bogor.

Novoselec J, Z Antunovic, M Speranda, Z Steiner and T Speranda. 2009. Changes of thyroid hormones concentration in blood sheep depending on age and reproductive status. Italian Journal of Anim. Sci. 8(3):208-210.

NRC. 2007. Nutrient Requirement of Small Ruminants. Washington, D.C. Natl. AcaS Pres.

Nudda A, G. Battacone, M Decandia, M Acciaro, F Aghini-Lombardi, M Frigeri and G Pulina. 2009. The effect of dietary iodine supplementation in dairy goats on milk production traits and milk iodine content. J Dairy Sci. 92(10):5133-5138. 
Obst JM and Z Napitupulu. 1984. Milk yield of Indonesian goats. Proceeding of the Australian Society of Anim Prod. 15:501-504.

Paulikova I, G Kovac, J Bires, S Paulik, H Seidel and O Nagy. 2002. lodine toxicity in ruminants. Veterinary Medicine-Czech. 47(12):343-350.

Ranjhan SK. 1980. Animal Nutrition in Tropics. $2^{\text {nd }}$ Ed. Vikas Publishing House PVT LTD. 350 pp.

Somjen D, M Grafi-Cohen, G Weisinger, Elzkharov, O Sharon, Z Kraiem, D Fliss, D Zikk, F Kohen and N Stern. 2012. Growth inhibition of human thyroid carcinoma and goiter cells in vitro by isoflavone derivative 7-(O)-carboxymethyl daidzein conjugated to $\mathrm{N}$-t-boc-hexylenediamine. Thyroid. 22(8):809-813.

Swanson EW and JK Miller. 1973. Restoration of normal lactation in hypothyroid cows. J Dairy Sci. 56:92-97.

Thrift TA, A Bernal, AW Lewis, DA Neuendorff, CC Willard and RD Randel. 1999. Effects of induced hypothyroidism on weight gains, lactation, and reproductive performance of primiparous Brahman cows. J. Anim. Sci. 77:1844-1850.

Todini L. 2007. Thyroid hormones in small ruminants: effects of endogenous, environmental and nutritional factors. Animal. 1:997-1008.

Todini L, A Malfatti, A Valbonesi, M TrabalzaMarinucci and A Debenedetti. 2007. Plasma total T3 and T4 concentrations in goats at different physiological stages, as affected by energy intake. Small Rum. Res. 68(3):285-290.

Umaly RC and LW Poel. 1970. Effects of various concentrations of iodine as potyassium iodide on growth of barley, tomato and pea in nutrient solution cultures. Annals of Botby. 34:919-928.

Watts MJ and CJ Mitchell. 2009. A pilot study on iodine in soils of Greater Kabul and Honorry.

Weng HX, AL Yan, CL Hong, LL Xie, YC Qin and CQ Cheng. 2008. Uptake of different species of iodine by water spinach and its effect to growth. Biological Trace Element Res. 124:184-193. 